\title{
Initial Study on Building Information Modeling Adoption Urgency for Architecture Engineering and Construction Industry in Indonesia
}

\author{
Fauzan Alfi Agirachman ${ }^{1 *}$, Ilham Fajar Putra ${ }^{2} \&$ Adam Angkawijaya ${ }^{2}$ \\ ${ }^{1}$ School of Architecture, Planning and Policy Development, Institut Teknologi Bandung, Indonesia \\ ${ }^{2}$ BicaraBIM Research Team, Bandung, Indonesia
}

\begin{abstract}
This paper presents our initial study on Building Information Modeling (BIM) adoption urgency for architecture, engineering and construction (AEC) industry in Indonesia. Currently, BIM is being adopted by many countries around the world because of its' efficiency and other benefits. Meanwhile, most of AEC industries in Indonesia still using the conventional method and there are no regulations from Indonesian AEC authority for adopting BIM. With that situation, a study of BIM adoption in Indonesian AEC industries is important. This study uses a qualitative approach with explorative type. Input from the survey is evaluated qualitatively using content analysis, distribution analysis and correspondence analysis method. Based on analysis result, it shows that BIM as a mean to encourage a more sustainable approach in AEC industry is still in its development phase but it shows great potentials and it gives stakeholders a better way to achieve sustainable built environment. Current lack of awareness and understanding of BIM in Indonesia, particularly in the education sector, is a key factor that impedes BIM adoption and one that can be addressed by integrating BIM into AEC curriculum. Government and practitioners alike need to develop a strategic roadmap to pave way for successful BIM implementation.
\end{abstract}

\section{Introduction}

Building Information Modeling (BIM) has been used both as a modeling tool and design-construction process, around the world. Eastman et.al. [1] mentioned that Building Information Modelling is one of the promising developments in the industry, especially in architecture, engineering and construction (AEC) industry. Stakeholders are able to create a more accurate model to will-be-constructed building and see any problems long before the construction happens. At the same time, BIM is also a whole new approach which requires implementation of new policies, contracts and relationships among project stakeholders [2].

Currently, BIM is being adopted by many countries around the world because of its efficiency and other benefits. United States of America (USA) is one of the countries that's pioneering the adoption of BIM nationwide. In the United States, National 3D-4D BIM program was already launched in 2003 by General Services Administration (GSA) [3]. Wong et.al. [3] mentioned that half of the industry in the USA was using BIM or BIM-related tools in 2009 alone. It represents $75 \%$ of usage compared to the level in 2007. Also, US National Building Information Modeling Standard was released in 2006 to support the adoption. GSA also released a BIM Guide that helps designers to develop final concept designs that require them to submit a BIM
Industry Foundation Classes (IFC) model defined by the buildingSMART organization.

In Europe, BIM also adopted by a lot of countries such as Finland and Denmark. In Finland, BIM adoption is led by Senate Properties which is the public owner running pilot projects using BIM and IFC [3]. BIM also being researched in Finland by Helsinki University of Technology and Tampere University of Techno. Those institutions are performing research and development in BIM for educational context. Meanwhile, in Denmark, BIM was initiated by at least three public owners: The Palaces and Properties Agency, The Danish University and Property Agency and Defence Construction Service. They have a significant impact due to IFC model requirements.

In Asia itself, Singapore is known as one of first nation adopting and implementing BIM nationwide specifically in public sector. BIM development and implementation in Singapore is started by Construction and Real Estate Network (CORENET), an initiative launched by the government in 1995. Currently, most of development and implementation is led by the Building Construction Authority (BCA) aiming $80 \%$ of construction industry adopting BIM by 2015. This intention was to improve industry productivity up to $25 \%$ over the next decade. In Hong Kong, where under the Works Branch of the Development Bureau (DevB),

\footnotetext{
* Corresponding author: fauzan.alfi@gmail.com
} 
BIM was introduced into the existing CAD standard for Works Projects in 2007. With that phenomenon, a study of BIM adoption in Indonesian AEC industries is important.

Currently, in Indonesia, most of AEC industries in Indonesia are still using conventional methods, such as $3 \mathrm{D}$ modelling and $\mathrm{CAD}$, and there is no regulation from Indonesian authority for adopting BIM as part of building design and construction process. In this paper, we would like to present our initial study on BIM adoption urgency in Indonesia and discuss how AEC industries are able to implement BIM in Indonesia as a sustainable approach for themselves as industries and also for the environment itself.

\section{Research Method}

This research is using qualitative [4] and explorative [5] research method. Explorative qualitative research is done to get data with several information possibilities from respondents and also to get factors from the gathered information. Study input based on survey data that had been taken from Indonesian BIM Implementation and Protocol Seminar held by Study Program of Architecture ITB in 2016. The survey was a questionnaire form that answered by 106 respondents from various stakeholders in AEC industries in Indonesia.

Data analysis is done qualitatively using content analysis, distribution analysis and correspondent analysis method. The content analysis method is used first to enrich information about how urgent the implementation of BIM in AEC industry for Indonesia. Then, distribution analysis is done to get the frequency of dominant and non-dominant answers from respondent related with BIM adoption urgency. In the end, correspondent analysis is done to see the correspondent between respondent's profession and BIM urgency to see the needs of each profession.

\section{Analysis \& Interpretation}

Content analysis from questionnaire result is done to create a base statement about the importance of BIM adoption in Indonesia. Answers which can be analyzed in the content analysis must directly correlated or relevant to the issues. The first step in content analysis method is open coding. Open coding is a phase to identify all keywords of respondents' statement in survey answers. Here's one for the example,

"BIM is important to be implemented because of the viability of design process until construction. From the base information that can be collected, a design team can explore and choose the best design decision in the process. Besides of that advantage, BIM help designer to deliver information to other engineer consultants using visual presentation. Information that modelled using BIM in construction phase will become an accurate database for construction (material, dimension, method, etc.)" (One of the respondent's answer)

Based on that answer, there are several keywords like "viability on design process", "make/help better coordination" \& "accurate building information" are categorized as "BIM adoption advantages". After finishing the open coding phase, axial coding is done to categorize keywords into specific categories. Categorizing is done by doing several discussions with researchers to prevent bias result.

Several categories that come up from axial coding process described in Table 1 below,

Table 1. Partial Axial Coding Result from Questionnaire

\begin{tabular}{|c|c|c|c|}
\hline No & $\begin{array}{c}\text { Main } \\
\text { Category }\end{array}$ & Category & Sub Category \\
\hline \multirow{13}{*}{1} & \multirow{13}{*}{ Urgent } & \multirow{6}{*}{ Efficiency } & Time \\
\hline & & & Cost \\
\hline & & & Design Process \\
\hline & & & $\begin{array}{l}\text { Production } \\
\text { Process }\end{array}$ \\
\hline & & & Human Resource \\
\hline & & & Tools \\
\hline & & $\begin{array}{l}\text { Project } \\
\text { Control }\end{array}$ & - \\
\hline & & $\begin{array}{c}\text { Coordination } \\
\text { and } \\
\text { Collaboration }\end{array}$ & - \\
\hline & & $\begin{array}{l}\text { External } \\
\text { Demands }\end{array}$ & - \\
\hline & & $\begin{array}{l}\text { Information } \\
\text { Processing }\end{array}$ & - \\
\hline & & Future Needs & - \\
\hline & & Accuracy & - \\
\hline & & $\begin{array}{l}\text { Large Scale } \\
\text { Project }\end{array}$ & - \\
\hline \multirow{3}{*}{2} & \multirow{3}{*}{ Not Urgent } & $\begin{array}{c}\text { Lack of } \\
\text { Regulation }\end{array}$ & - \\
\hline & & $\begin{array}{c}\text { Lack of } \\
\text { Knowledge }\end{array}$ & - \\
\hline & & $\begin{array}{l}\text { Adaptation } \\
\text { Problem }\end{array}$ & - \\
\hline
\end{tabular}

After processing keywords into several categories, next phase is Distribution Analysis that intended to count frequency that shows up from respondents' answers. Distribution analysis reveals how important of each 
category for this BIM urgency factor in Indonesia. From this process, sub-category "design process" from "efficiency" category is known as most frequently answered by correspondent in BIM urgency question. More results are shown in Table 2.

Table 2. Analysis Distribution Results

\begin{tabular}{|c|c|c|c|c|}
\hline No & $\begin{array}{c}\text { Main } \\
\text { Category }\end{array}$ & Category & $\begin{array}{c}\text { Sub } \\
\text { Category }\end{array}$ & Freq. \\
\hline \multirow{13}{*}{1} & \multirow{13}{*}{ Urgent } & \multirow{6}{*}{ Efficiency } & Time & 8 \\
\hline & & & Cost & 3 \\
\hline & & & $\begin{array}{c}\text { Design } \\
\text { Process }\end{array}$ & 18 \\
\hline & & & $\begin{array}{c}\text { Production } \\
\text { Process }\end{array}$ & 11 \\
\hline & & & $\begin{array}{c}\text { Human } \\
\text { Resource }\end{array}$ & 1 \\
\hline & & & Tools & 1 \\
\hline & & $\begin{array}{l}\text { Project } \\
\text { Control }\end{array}$ & - & 8 \\
\hline & & $\begin{array}{c}\text { Coordination } \\
\text { and } \\
\text { Collaboration }\end{array}$ & - & 12 \\
\hline & & $\begin{array}{c}\text { External } \\
\text { Demands }\end{array}$ & - & 10 \\
\hline & & $\begin{array}{l}\text { Information } \\
\text { Processing }\end{array}$ & - & 4 \\
\hline & & Future Needs & - & 5 \\
\hline & & Accuracy & - & 7 \\
\hline & & $\begin{array}{c}\text { Large Scale } \\
\text { Project }\end{array}$ & - & 4 \\
\hline \multirow{3}{*}{2} & \multirow{3}{*}{ Not Urgent } & $\begin{array}{c}\text { Lack of } \\
\text { Regulation }\end{array}$ & - & 1 \\
\hline & & $\begin{array}{c}\text { Lack of } \\
\text { Knowledge }\end{array}$ & - & 7 \\
\hline & & $\begin{array}{l}\text { Adaptation } \\
\text { Problem }\end{array}$ & - & 1 \\
\hline
\end{tabular}

Last step to analyze base information about BIM urgencies in Indonesia is selective coding phase by doing correspondent analysis. This phase identifies the correlation of correspondent profession with their perspective of BIM urgency. This analysis described by ward hierarchical clustering in Figure $1 \& 2$.

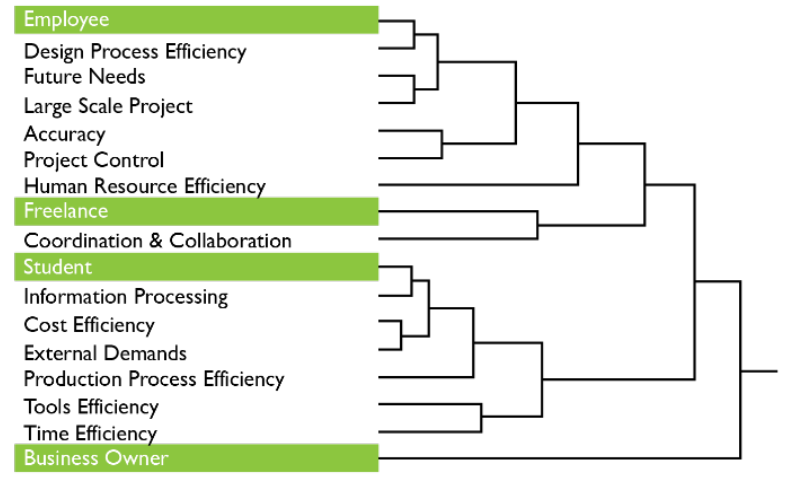

Fig. 1. Relationship Between Respondent's Work Sector and Categories of BIM Adoption Urgency

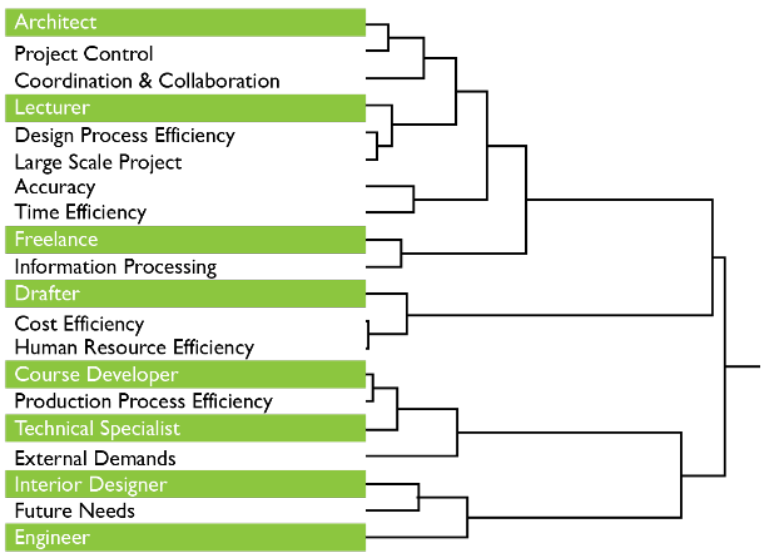

Fig. 2. Relationship Between Respondent's Occupation and Categories of BIM Adoption Urgency

Figure 1 describes the correlation between urgencies categories and specific profession that closely related to it. Meanwhile in Figure 2, it describes the similar correlation but profession view in general. Based on that figure, "design process efficiency" category is highly correlating with architect and lecturer's perspective about BIM. Other important categories for BIM urgency based on Table 2 are closely correlated with architect, course trainer and technical specialist perspective or expectation when using BIM methods for work. Comprehensive analysis about correlation between important factor and job sector is described in Table 3. This analysis result becomes our basic information to seek further strategies on BIM adoption urgencies in Indonesia.

Table 3. Correspondent Analysis Table on BIM Adaption Urgency Issues in Indonesia

\begin{tabular}{|c|c|c|c|}
\hline No & $\begin{array}{c}\text { Category/ } \\
\text { Sub } \\
\text { Category }\end{array}$ & $\begin{array}{c}\text { Work } \\
\text { Sector/ } \\
\text { Occupation }\end{array}$ & Summary \\
\hline 1 & $\begin{array}{c}\text { Efficiency/ } \\
\text { Time }\end{array}$ & $\begin{array}{c}\text { Education/ } \\
\text { Lecturer }\end{array}$ & $\begin{array}{c}\text { Time efficiency } \\
\text { become main } \\
\text { concern in } \\
\text { educational } \\
\text { institution }\end{array}$ \\
\hline 2 & $\begin{array}{c}\text { Efficiency/ } \\
\text { Design }\end{array}$ & $\begin{array}{c}\text { Professional } \\
/\end{array}$ & $\begin{array}{c}\text { Lecturer \& } \\
\text { Architect are }\end{array}$ \\
\hline
\end{tabular}




\begin{tabular}{|c|c|c|c|}
\hline & Process & $\begin{array}{c}\text { Lecturer \& } \\
\text { Architect }\end{array}$ & $\begin{array}{l}\text { important sector } \\
\text { that most concern } \\
\text { at design process } \\
\text { efficiency in BIM }\end{array}$ \\
\hline 3 & $\begin{array}{l}\text { Efficiency/ } \\
\text { Production } \\
\text { Process }\end{array}$ & $\begin{array}{l}\text { Education/ } \\
\text { Course } \\
\text { Trainer \& } \\
\text { Technical } \\
\text { Specialist }\end{array}$ & $\begin{array}{l}\text { Production process } \\
\text { efficiency become } \\
\text { main concern in } \\
\text { BIM training } \\
\text { sector both inside } \\
\text { corporation or } \\
\text { independent } \\
\text { training facilities }\end{array}$ \\
\hline 4 & $\begin{array}{l}\text { Project } \\
\text { Control }\end{array}$ & $\begin{array}{l}\text { Professional } \\
\text { /Architect }\end{array}$ & $\begin{array}{l}\text { Architects that } \\
\text { work in a company } \\
\text { are concern for } \\
\text { BIM method } \\
\text { abilities to help } \\
\text { project control } \\
\text { aspect }\end{array}$ \\
\hline 5 & $\begin{array}{l}\text { Coordinati } \\
\text { on \& } \\
\text { Collaborati } \\
\text { on }\end{array}$ & $\begin{array}{c}\text { Freelancer/ } \\
\text { Architect }\end{array}$ & $\begin{array}{c}\text { Freelancer } \\
\text { Architect is sector } \\
\text { that most concern } \\
\text { about coordination } \\
\& \text { collaboration } \\
\text { aspect in BIM }\end{array}$ \\
\hline 6 & $\begin{array}{l}\text { External } \\
\text { Demands }\end{array}$ & $\begin{array}{l}\text { Education/ } \\
\text { Technical } \\
\text { Specialist }\end{array}$ & $\begin{array}{l}\text { External demands } \\
\text { (trends \& } \\
\text { competition) is } \\
\text { main concern in } \\
\text { companies BIM } \\
\text { training sector }\end{array}$ \\
\hline 7 & Accuracy & $\begin{array}{l}\text { Professional } \\
\text { /Architect }\end{array}$ & $\begin{array}{c}\text { BIM abilities to } \\
\text { provide accurate } \\
\text { building } \\
\text { information also } \\
\text { become architect } \\
\text { concern }\end{array}$ \\
\hline 8 & $\begin{array}{c}\text { Not } \\
\text { Urgent/ } \\
\text { Lack of } \\
\text { Knowledge }\end{array}$ & $\begin{array}{l}\text { Professional } \\
\text { /Architect }\end{array}$ & $\begin{array}{l}\text { Some architects } \\
\text { that work in } \\
\text { companies concern } \\
\text { that BIM is not } \\
\text { urgent because } \\
\text { lack of BIM } \\
\text { education }\end{array}$ \\
\hline
\end{tabular}

\section{Discussion}

Based on survey answers, there are several expected benefits from BIM usage by AEC actors in Indonesia. Further studies will be needed to evaluate BIM usage development and user expectation.

\subsection{Design Process Efficiency}

From several expected BIM benefits, design process is the most frequently used answer. In design process, sustainability \& energy efficiency become fundamental factor in making design decision. It really depends on project owner's perspective because there is still some project owner who sees the project just in economical aspect which sometimes leads to much energy waste or not sustainable method way of work. Implementation of $\mathrm{BIM}$ on design method is not simultaneously matching up with way of work of AEC industries in Indonesia.
BIM software that shows up with the pretty expensive price also becomes a problem for small firm and consultant. Since BIM design methodology is based on database and information management, only large architecture \& engineering consultant that can initiate comprehensive studies in BIM implementation. Implementation of BIM methodologies in whole design process also has different phase compared with conventional design methodologies that have been implemented in Indonesia right now (CAD methods). This difference between each method shown in Figure 3.
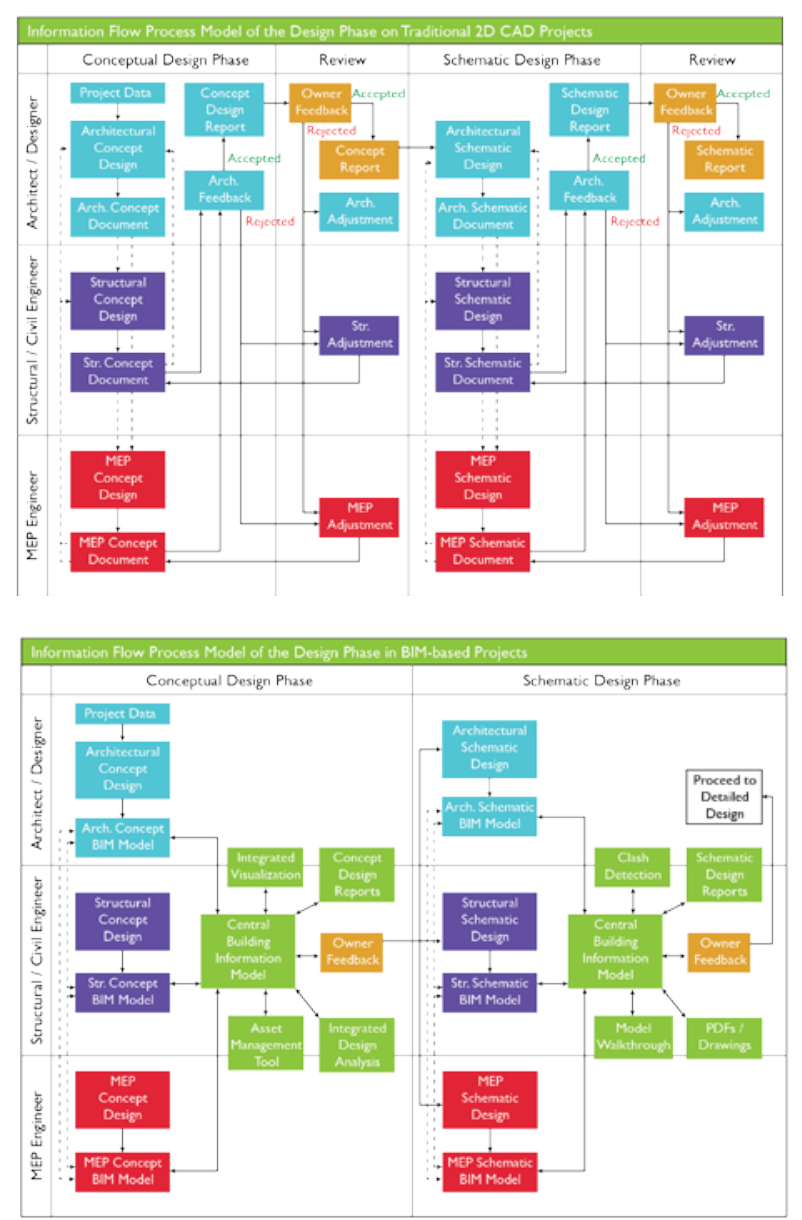

Fig. 3. Design Process Difference Between Traditional Method and BIM Method [9]

\subsection{Coordination \& Collaboration}

Good \& efficient coordination between AEC sectors while doing productive collaboration in project lifecycle is another BIM implementation advantage that mentioned by many respondents. Though, in Indonesia, work management \& project phases are regulated by guideline from several institutes that regulating public infrastructure development. So that is why BIM method implementation is easier to implement in private sector. Because BIM method depends on information exchange \& management into building model, it is hard to not share confidential company information when doing BIM collaboration. Without support from a government institution to control \& provide BIM information right \& law regulations, 
BIM collaboration will be hard to implement both in public \& private sector.

\subsection{Production Process Efficiency}

Document integration, organized clash detection, construction progress simulation and many production processes support that provided by BIM implementation are also the main reason why AEC actors \& industries in Indonesia need to start BIM adoption. Indonesia has a regulation that describes documentation drawing in infrastructure project, construction operational standards, but it still lacks detailed guideline \& information that control product quality issues. Even though, this standard \& guideline issue still need to be fixed immediately. In 2015, Government of Jakarta launched $\mathrm{CAD}$ layering guideline \& standard for project procurement in public sector. This kind of guideline will help settlement process for creating future BIM proto col $\&$ guideline in Indonesia.

Also, the maturity of BIM \& stakeholder capacity plays a great role in BIM implementation. Common value about BIM among stakeholders for shaping the proactive market needs to be created [6]. Better knowledge about this BIM maturity for AEC actors is important to do efficient production process.

\subsection{External Demands}

More valuable deliverables in business competition and keep up with technological trends also the value that many AEC actors seek in implementing BIM methods. BIM methods initially implemented for the public infrastructure project in the USA at 2003 [7]. After years of study and development, BIM implementation turns out increasing efficiency and many aspects of AEC industries. Since around 2010 until nowadays, many $\mathrm{AEC}$ industries and academic institutions in Indonesia still doing research \& improvement in BIM implementation on infrastructure \& business development. Recently in 2017, Institut BIM Indonesia (iBIMi) was officially launched to gather Indonesian AEC actors for creating future strategies, protocol and many other developments that will be needed for BIM implementation in Indonesia.

\subsection{Time Efficiency}

Accomplishing project lifecycle in less amount of time is another BIM beneficial factor that respondent seeks in BIM implementation. This advantage comes from several integrated procedures that facilitated in BIM tools and workflow. Even further, efficiency potential lies in coordination and collaboration facilities that provide clash detection \& revision distribution in real time. Also without investing effort in BIM education, proper training \& technologies, BIM implementation in
Indonesia will turn out to become "silver bullet syndrome" in time management. By that condition, rather than make time efficiency by implementing BIM method, it will take much time to finish project compared to conventional method.

\subsection{Project Control and Accuracy}

Project control \& accuracy are another BIM implementation advantage that helps BIM, coordinator/manager, to calculate, record \& simulate future probability in a project then make a decision based on it. To have fully implemented BIM project in Indonesia, the same type of issue that been explained before about lack of technological and human resource education in BIM method are big obstacle to meet this condition.

\subsection{Lack of BIM Knowledge}

Based on several discussions above, lack of BIM knowledge for AEC actors about good BIM implementation in project lifecycle become the main reason why BIM implementation is still not an urgent condition for Indonesia right now. Taylor and Bernstein [8] explored four paradigms of BIM implementation at the firm level: visualization, coordination, analysis and supply chain integration. With firm's increasing project experience, these paradigms evolve along a trajectory from visualization, to coordination, to analysis and finally to supply chain integration [7]. So, better knowledge about BIM implementation won't be achieved either if AEC actor or firm in Indonesia never try to implement it properly.

\section{Conclusion}

$\mathrm{BIM}$ as a mean to encourage more sustainable approach in AEC industry in Indonesia is still in its development phase but it shows great potentials and it gives stakeholders a better way to achieve sustainable built environment. This initial study for BIM urgencies in Indonesia leads up to 6 important aspects of consideration for AEC stakeholders for adopting BIM methods in their project. These aspects are designed to process efficiency, coordination and collaboration, production process efficiency, external demands, time efficiency, and project control and accuracy.

Current lack of awareness and understanding of BIM in Indonesia, particularly in the education sector, is a key factor that impedes BIM adoption and one that can be addressed by integrating BIM into AEC curriculum. Government and practitioners alike need to develop a strategic roadmap to pave way for successful BIM implementation. 
Greater adoption of BIM will be possible if stakeholders have better understanding of BIM and its usage through education, regulation and protocols and standardization, it also takes time and collaborative effort from AEC stakeholders to reach its maximum potential, therefore early adoption and collaboration is imperative so that users will be able to achieve a better built environment sooner, with Building Information Modeling.

\section{References}

1. Eastman, C., Teicholz, P., Sacks, R. \& Liston, K., BIM Handbook: A Guide to Building Information Modeling for Owners, Managers, Designers, Engineers, and Contractors, Second Edition, John Wiley \& Sons, Inc., 1-2, 2011.

2. Aranda-Mena, G., Crawford, J., Chevez, A. and Froese, T., Building information modelling demystified: does it make business sense to adopt BIM?, International Journal of Managing Projects in Business, 8(3), pp. 419-420, 2009.

3. Wong, A.K.D., Wong, F.K.W. and Nadeem, A., Attributes of Building Information Modelling Implementations in Various Countries, Architectural Engineering and Design Management, Vol. 6, pp. 288-302, 2010.

4. Creswell, J.W., Research Design: Qualitative, Quantitative, and Mixed Methods Approaches, Third Edition, SAGE Publication, 173-190, 2009.

5. Groat, L.N. \& Wang, D., Architectural Research Methods, Second Edition, John and Wiley Inc., 215-258, 2013.

6. Zhang, D., Wei, L. \& Rowlinson, S., Exploring BIM Implementation: A Case Study in Hong Kong, pp. 5-8, 2010.

7. Wong, A.K.D., Wong, F.K.W. \& Nadeem, A., Government Roles in Implementing Building Information Modelling System, pp. 4, 2010.

8. Taylor, J.E. \& Bernstein, P.G., Paradigm Trajectories of Building Information Modeling Practice in Project Networks. Journal of Management in Engineering, pp. 25,69, 2009. 